\title{
Judges and Judgment: In Praise of Instigators
}

\author{
Kathryn Judge $\dagger$
}

\section{INTRODUCTION}

This Essay is about mutual funds. Because of that, it may put many to sleep long before we get to the heart of the matter. I encourage you right now to stay awake, or at least keep one eye propped open. For embedded in this story about mutual funds, rent seeking, the challenge of separating the good and the bad, and the even greater challenge of respecting autonomy in an environment where so many choices seem to be bad ones, is the story of a judge. That judge is the Honorable Richard A. Posner, aka RAP, Dick, Professor Posner, the one to be feared, the one to be revered, the one who inspires, the one who causes many to perspire, and the one who somehow gets it right even when he is wrong (and he is sometimes wrong). It is a story of how he judges. It is a story of curiosity and truth seeking. It is a story of respecting process and precedent while not being overly constrained by convention or rules. It is also a story of constantly seeing things anew, even when that requires letting go of views that seemed true when first embraced. It is a story of positionality and insight, and law and humanity, and the perfection of embracing imperfection. It is a story of using stories to help others see, and the power and limits of such methods.

Although this may all sound a little too new-agey to possibly be an account of Judge Richard Posner, let me assure you that there are reasons to use this type of language to understand who he is and how he judged. And let me further assure you that in the process of trying to uncloak something new about the brilliant and prolific Judge Posner, this Essay will also seek to unmask something about how our legal system does and should work. For although there will never be another Judge Posner, his approach

$\dagger \quad$ Professor of Law, Columbia Law School; Research Member, European Corporate Governance Institute. The author would like to thank John Coates, John Morley, and Quinn Curtis for helpful comments; Christian Ronald for excellent research assistance; and Lawrence Lessig and Jesse Eisinger for inspiration. Mistakes are mine alone. 
to judging holds lessons for all of us. I will suggest that much of Judge Posner's depth came not from his remarkable mind but from his steadfastness in not allowing the legend that grew up around him to blunt his curiosity or contort his view of himself. Although not one for false modesty, he conscientiously, even if not consciously, avoids living on a cloud. The heart of what makes him a legend is less his brilliant intellect than his wisdom. And, fortunately for the rest of us, a mind need not be anywhere near as sharp as his to learn something from his capacity to hold tensions-humility enabled by utter self-assurance, fairness through allowance for difference, transcendence that rests upon and is grounded in human fallibility. Most important, for purposes of this Essay, was his treatment of the law as a corpus both greater than but inherently of the people who make it and in whose service it is deployed.

In a methodology that can be defended only by the meekness of the conclusions it supports, this Essay weaves together the evolution of one case with Judge Posner's writing about judging and some personal observations to speculate on why the law needs more individuals like Judge Posner. Alongside doing right by litigants in any individual suit, producing "good" law is a critical function of the judicial system. Recognizing a particular court's position within a multitiered judicial system, and situating that system within a governance regime that imposes frictions on legislative and regulatory action, is critical to assessing what judges should and should not do. Given ongoing learning, changing environments, and the potential for law to take form in the backwaters without anyone focusing on what it should be, the law should sometimes evolve. Judges that sit below the top of the hierarchy can aid this process by sometimes serving as instigators, flagging areas in which the law is ill suited to the task at hand. This is but one role and should not always triumph, but also should not be ignored. The occasional pragmatic instigator may stir up some trouble, but she can also play a critical role in keeping the law alive. Allowing some judges some of the time to ask the tough questions about what the law is and ought to be even when resolving a case is critical to the health of the law. The core claim of this Essay is thus a call to embrace instigators as an essential element of, rather than an affront to, an effective judiciary.

On the offhand possibility that you are wondering what any of this has to do with mutual funds, let me cut to the chase. The backbone of this Essay is a case about whether a mutual fund 
investment advisor breached a fiduciary duty owed to its investors by charging too high of a fee for its services. ${ }^{1}$ This is a tricky area of the law, as most actively managed mutual funds charge fees in excess of what their returns can justify, and yet investors keep buying them. The case was decided by three of Judge Posner's colleagues on the Seventh Circuit Court of Appeals. Had it not been for Judge Posner, the case likely would have died there. But Judge Posner, never one to minimize his workload, read that opinion when the lawyers took the often pro forma step of seeking a rehearing. And despite (or perhaps because) that unanimous opinion had been authored by Frank Easterbrook, Judge Posner decided that the reasoning was suspect and that the case should be reheard en banc. In a dissent to the denial of rehearing the case en banc, Posner argued that Judge Easterbrook had created a circuit split without so acknowledging and that the case deserved the attention of the full Seventh Circuit. Although Posner convinced only four of his Seventh Circuit colleagues to see the case his way, his opinion did get the attention of the Supreme Court. The Court granted cert and soundly rejected Judge Easterbrook's approach, albeit in a narrow decision that largely reverted the law to where it stood before either Posner or Easterbrook got involved.

With respect to the law governing mutual funds, the Supreme Court's decision was a missed opportunity, but no great tragedy. Others have written, in great detail, on the mechanics of mutual fund fee litigation and the significance of the various opinions rendered in this case. ${ }^{2}$ The account here addresses these issues, but only as a means rather than an end. The Essay instead uses this dispute as a lens into lawmaking - the role of courts and particular judges on those courts; the role of lawyers who bring suits and those who defend against them; and the role of Congress, as both body and construct, in how judges apply the laws that Congress adopts. Following in the spirit of Judge Posner, and hence exercising my prerogative to project onto Posner things he

\footnotetext{
1 See generally Jones v Harris Associates, 527 F3d 627 (7th Cir 2008).

2 See generally, for example, Quinn Curtis and John Morley, The Flawed Mechanics of Mutual Fund Fee Litigation, 32 Yale J Reg 1 (2015); John C. Coates IV, The Downside of Judicial Restraint: The (Non-)Effect of Jones v. Harris, 6 Duke J Const L \& Pub Pol 58 (2010); M. Todd Henderson, Justifying Jones, 77 U Chi L Rev 1027 (2010); John Morley and Quinn Curtis, Taking Exit Rights Seriously: Why Governance and Fee Litigation Don't Work in Mutual Funds, 120 Yale L J 84 (2010); Lyman Johnson, A Fresh Look at Director "Independence": Mutual Fund Fee Litigation and Gartenberg at Twenty-Five, 61 Vand L Rev 497 (2008).
} 
might never say himself, I will argue that Judge Posner embodies the importance of boldness and individualism to the law and that humble pragmatists may be particularly good in this role.

\section{THE CASE}

\section{A. The Setup}

We live in a world where many actively managed mutual funds are a scam. Not in a Bernie Madoff-type way. Most asset managers are not fraudsters, and few regulated funds are Ponzi schemes. Many mutual fund advisors believe, quite fervently, in the value of the work they are doing. Some are even right to believe that they create value. Nonetheless, the overall picture is bleak. Herd behavior is common. ${ }^{3}$ Professors Eugene Fama and Kenneth French found that "on average, active mutual funds do not produce gross returns above (or below) those of passive benchmarks," which is bad news for investors given the higher fees for active funds. ${ }^{4}$ Another recent study found that "over the 10-year investment horizon, $85.36 \%$ of large-cap managers, $91.27 \%$ of mid-cap managers, and $90.75 \%$ of small-cap managers failed to outperform" the relative benchmark, and the performance was almost as bleak when evaluating their performance over shorter time horizons. ${ }^{5}$ And even a recent study suggesting that mutual fund managers do create value found no evidence that the value created is passed onto investors rather than captured as rents. ${ }^{6}$

After the 2008 financial crisis, investors seemed to wake up to these facts, as reflected in the rapid growth of lower fee index funds and passive exchange-traded funds. ${ }^{7}$ Nonetheless, roughly $\$ 10$ trillion remains invested in actively managed mutual funds. That's right: $\$ 10$ trillion flowing through funds that charge fees

\footnotetext{
3 See, for example, Richard W. Sias, Institutional Herding, 17 Rev Fin Stud 165, 167 (2004)

4 Eugene F. Fama and Kenneth R. French, Luck versus Skill in the Cross-Section of Mutual Fund Returns, 65 J Fin 1915, 1923 (2010).

5 Aye M. Soe and Ryan Poirier, SPIVA U.S. Scorecard: Mid-Year $2016{ }^{*} 1$ (S\&P Global 2016), archived at http://perma.cc/ZBA2-HVNP.

6 See Jonathan B. Berk and Jules H. van Binsbergen, Measuring Skill in the Mutual Fund Industry, 118 J Fin Econ 1, 16 (2015) (finding that the average mutual fund manager does create value but that "the average net alpha across all funds is not significantly different from zero, so there is no evidence that investors share in the fruits of this skill").

7 For why this raises new concerns, see Charles Stein, Active vs. Passive Investing (Bloomberg, Dec 4, 2017), archived at http://perma.cc/JRN7-5J6B.
} 
that in nine out of ten cases swamp any value provided. ${ }^{8}$ That market and those fees are what's at stake in this case.

Mutual funds sold to the public, whether open or closed, active or passive, are regulated as "registered investment companies," a status created by the Investment Company Act of $1940 .{ }^{9}$ This Act imposes a range of requirements on such funds while largely exempting private funds, such as hedge funds and private equity funds, sold only to institutions and very wealthy individuals. The notion that investment advisers have "a fiduciary duty with respect to the receipt of compensation for services" was added as $\S 36(\mathrm{~b})$ of the Act in $1970 .{ }^{10}$ A little more than a decade later, the Second Circuit held in Gartenberg $v$ Merrill Lynch Asset Management, Inc ${ }^{11}$ that this obligation included a duty not to charge excessive fees for the services provided and promulgated a six-factor test for determining whether fees are excessive. ${ }^{12}$ Most courts subsequently confronted with a $\S 36(\mathrm{~b})$ claim have followed some version of the Gartenberg test. ${ }^{13}$ Section 36(b) liability was thus a largely settled, even if not particularly satisfying, area of law until 2009.

\section{B. The Seventh Circuit Debate}

In 2009, Judge Easterbrook and two colleagues heard an appeal from Jerry Jones and other owners of Oakmark mutual funds claiming that the adviser to Oakmark funds had breached its $§ 36(b)$ fiduciary obligations. ${ }^{14}$ Judge Easterbrook agreed with the lower court that the case should be dismissed, but he also went out of his way to "disapprove" of the Gartenberg standard

8 In previous work, I've offered a novel explanation for the amount of money flowing into such funds, suggesting that we can best understand these decisions as influenced by stock brokers and other intermediaries, who regularly help retail investors wade through the nearly ten thousand mutual fund choices available, and who earn extra when their clients buy expensive funds. See Kathryn Judge, Intermediary Influence, $82 \mathrm{U}$ Chi L Rev 573, 588 (2015); Kathryn Judge, Fee Effects, 98 Iowa L Rev 1517, 1527 (2013).

954 Stat 789 , codified at 15 USC $\$ 80 \mathrm{a}-1$ et seq.

1015 USC $\S 80 a-35(b)$; Investment Company Amendments Act of 1970, Pub L No 91547, 84 Stat 1413, 1429, codified in various sections of Title 15 (emphasis added).

11694 F2d 923 (2d Cir 1982).

12 Id at 929-30.

13 See Jones $v$ Harris Associates, 559 US 335, 343-44 (2010) (noting that "until the Seventh Circuit's decision below, something of a consensus had developed regarding the standard set forth over 25 years ago in Gartenberg").

14 Jones $v$ Harris Associates, 527 F3d 627, 629 (7th Cir 2008). 
relied on by the district court.15 According to Easterbrook, "A fiduciary duty differs from rate regulation."16 In his assessment, this means that Section 36(b) creates a robust disclosure requirement and outlaws chicanery, but otherwise leaves to market forces the task of limiting the fees that mutual fund advisers charge their clients. He buttressed this position by analogizing the process through which mutual fund adviser fees are set to the processes establishing executive compensation. And he concluded by pointing to evidence that hedge fund managers are paid far more than mutual fund managers, making it "hard to conclude that Harris's fees must be excessive."17

The opinion has many Posner-like characteristics. It is courageous. It raises questions beyond those presented by the parties. It opts for a sweeping holding when a narrower one would suffice. And it does so in the spirit of improving the law. In Easterbrook's view, a fiduciary obligation, even one specific to compensation, is not sufficient to entangle judges in the messy business of secondguessing a price set in a market that, at least in some dimensions, is exceptionally competitive.

Judge Posner disagreed. He disagreed with Judge Easterbrook's reading of earlier Seventh Circuit cases, he disagreed with Easterbrook's failure to circulate the opinion prior to creating a circuit split, and, most importantly, he disagreed with Easterbrook's assumption that market forces could be relied on to keep fees in check.

Before going too deeply into Posner's opinion, it is worth recalling the setting in which he was writing. It was 2009. This was the year after Bear Stearns and AIG were bailed out, after Lehman Brothers failed, and after markets went into a tailspin. It was also deep into the greatest recession the country had experienced since the Great Depression. Americans were losing jobs and facing record numbers of foreclosures. The narrative of the crisis was that the system is rigged; the rich get richer as the poor get poorer. Wall Street gets saved while Main Street suffers. Bankers had brought the country to the brink with their greed and shenanigans, yet not one was going to jail for it. It was in this environment that Judge Posner read Judge Easterbrook's opinion

15 Id at 632

16 Id.

17 Id at 634. 
about the power of market forces and the problems of judicial intervention. It was against this background that Posner set about crafting a very different narrative.

"You want to talk executive compensation?" Posner asks. "Alright, let's look at executive compensation." Let's examine the "growing indications that executive compensation in large publicly traded firms often is excessive because of the feeble incentives of boards of directors to police compensation." 18 Note how much is packed into this sentence. According to Posner, executive compensation is broken. CEOs, Posner tells us, are "often" paid too much. This is not just an acknowledgment that markets are imperfect; it is a suggestion that they are flawed. And those flaws are evidenced in research documented in works about "Pay without Performance" and "Cronyism," and summed up in newspaper articles on "the Imperial CEO" and how "In the Boardroom, Every Back Gets Scratched."19 Posner then goes on to explain why Easterbrook's assumptions, ones that Posner might once have shared, have been revealed to be so erroneous. He talks about boardrooms full of executives who have a greater interest in protecting a world order that allows for excessive compensation and the way that compensation consulting is used to let boards off the hook for those decisions.

Posner goes on to explain: "Competition in product and capital markets can't be counted on to solve the problem because the same structure of incentives operates on all large corporations and similar entities, including mutual funds." 20 He quotes research on mutual funds finding that "business connections can mitigate agency conflicts," but they can also function as "channels for inefficient favoritism." ${ }_{21}$ This is Posner not just giving voice to the plaintiffs in the suit, but speaking to the frustrations with finance that permeated public discourse in the aftermath of the

18 Jones v Harris Associates, 537 F3d 728, 730 (2008) (Posner dissenting from denial of rehearing en banc) (emphasis added).

19 Id, citing Lucian Bebchuck and Jesse Fried, Pay without Performance: The Unfulfilled Promise of Executive Compensation 23-44 (Harvard 2004); Ivan E. Brick, Oded Palmon, and John K. Wald, CEO Compensation, Director Compensation, and Firm Performance: Evidence of Cronyism?, 12 J Corp Fin 403 (2006); Gary Wilson, How to Rein in the Imperial CEO, Wall St J A15 (July 9, 2008); Ben Stein, In the Boardroom, Every Back Gets Scratched, NY Times B9 (Apr 6, 2008).

20 Jones, $537 \mathrm{~F} 3 \mathrm{~d}$ at 730.

21 Id, quoting Camelia M. Kuhnen, Social Networks, Corporate Governance and Contracting in the Mutual Fund Industry (unpublished manuscript, Jan 4, 2006), archived at http://perma.cc/L93Y-D2TR, subsequently published as Business Networks, Corporate Governance, and Contracting in the Mutual Fund Industry, 64 J Fin 2185 (2009). 
housing market crash. And he's frank about the importance of the timing. As he explains, "Mutual funds are a component of the financial services industry, where abuses have been rampant" and are "more evident now." $22 \mathrm{He}$ is talking about finance as a site of bad behavior, a domain in which market processes and participants cannot be trusted. He is implicitly invoking the crisis to say that we now know better. Market forces are not just imperfect, as Easterbrook concedes; they are flawed. "The governance structure that enables mutual fund advisers to charge exorbitant fees is industry-wide." ${ }^{23}$ Exorbitant fees. Exorbitant.

Posner need not have gone this far. He could have noted that Easterbrook's approach created a circuit split and merited further consideration accordingly. Instead, Posner took Easterbrook's narrative as his starting point, and he flipped that narrative on its head. Like the good pragmatist he purports to be, Posner used experience rather than theory as his starting point. And he tells us that experience shows that the system is corrupt. Executives are overpaid; finance is full of tricksters. So maybe, just maybe, there is a role for the judiciary after all.

To be sure, Posner does not provide a satisfying explanation of what $\S 36(\mathrm{~b})$ obligations ought to entail or of the appropriate role of courts in adjudicating excessive fee claims. In taking Easterbrook's opinion as a starting point, he also reiterates a range of institutionally flawed analogies. There may be agency costs and other flaws in both the processes through which executive compensation and mutual fund fees are established, but those processes are sufficiently different that the comparison probably adds more confusion than clarity to the matter. Nonetheless, putting the opinion-or rather dissent-in context excuses at least some of these flaws. Not all opinions can or should serve the same function. Posner doesn't have the votes to make law. All he has is the opportunity to explain why the case merits further attention-why the opinion, as decided, is wrong. And knowing full well that his court sits one step down from the top of the federal judicial hierarchy, his aim seems clear: explain to those up above why they should agree to hear the case. 


\section{SCOTUS Chimes In}

The Supreme Court did indeed grant certiorari in Harris to resolve the question of the fiduciary obligations that a mutual fund adviser owes pursuant to $\S 36(\mathrm{~b})$. Consistent with Supreme Court Rule 10, and the structural understanding of the judicial system underlying this Essay, that decision reflected a view by at least four members of the Court that the state of the law, not the correctness or incorrectness of the decision below, justified the Court's attention. ${ }^{24}$ In further recognition of the distinct role of the Supreme Court, academics, industry groups, and others, including the Solicitor General, submitted sixteen amici briefs in which they provided thorough analyses of the issues at stake. ${ }^{25} \mathrm{As}$ one of these briefs, submitted by a group of law professors, explained: "By declining to define 'fiduciary duty' in Section 36(b), ... Congress ceded to the federal courts the duty of imbuing this concept with operational meaning." ${ }^{26}$ Judging by the Court's opinion, this exhortation fell largely on deaf ears.

In a unanimous opinion authored by Justice Samuel Alito, the Court rejected Judge Easterbrook's approach. ${ }^{27}$ The Court concluded that Gartenberg "has provided a workable standard for nearly three decades," and should accordingly be affirmed as the appropriate standard. ${ }^{28}$ It did so despite the fact, acknowledged by Justice Clarence Thomas in concurrence, that in those three decades, "no excessive fee suit has ever produced a verdict for plaintiffs." ${ }_{29}$ As further pointed out by Justice Thomas in concurrence, ${ }^{30}$ the Court also failed to address directly the tension between the language in Gartenberg, which seems to empower courts to exercise significant judgment with respect to the fairness of fees charged, with many subsequent lower court decisions that take a much narrower approach despite paying lip service to Gartenberg.

24 US S Ct Rule 10 ("A petition for a writ of certiorari is rarely granted when the asserted error consists of erroneous factual findings or the misapplication of a properly stated rule of law.").

25 For a list of amici briefs, see Jones $v$ Harris Associates (SCOTUSblog), archived at http://perma.cc/R7A4-JCHU.

26 Brief of Amici Curiae Law Professors in Support of Petitioners, Jones v Harris Associates, No 08-586, *9 (US filed June 15, 2009) (emphasis added).

27 Jones, 559 US at 353.

28 Id.

29 Quinn Curtis and John Morley, An Empirical Study of Mutual Fund Excessive Fee Litigation: Do the Merits Matter?, 30 J L Econ \& Org 275, 277 (2014).

30 Jones, 559 US at 354 (Thomas concurring). 
The vagueness that permeates much of the opinion gives way to clarity on one point. The Supreme Court disapproved of the back and forth between Easterbrook and Posner below. In Justice Alito's view, "The debate between the Seventh Circuit panel and the dissent from the denial of rehearing regarding today's mutual fund market is a matter for Congress, not the courts." ${ }_{11}$ In his view, it seems, examining the mutual fund marketplace in order to understand the context in which mutual fund fees are set and the effect of excessive fee litigation on that process is not a matter for judges, or at least not in the way Easterbrook and Posner approached it.

\section{PUtTing Jones IN CONTEXT}

As the extensive briefing reflects, there were a number of important issues before the Court in Jones. ${ }^{32}$ The Court's opinion answered few of them. In a piece summed up in its title, The Downside of Judicial Restraint: The (Non-)Effect of Jones v. Harris, Professor John Coates bemoans that in "cho[osing] to give little additional meaningful guidance to lower courts on what factors to use" when evaluating a $\S 36(\mathrm{~b})$ claim, the "primary beneficiaries" of the Supreme Court's decision are likely to be lawyers who bring and defend against such claims. ${ }^{33}$ In other subsequent work, Professors Quinn Curtis and John Morley explain the myriad reasons that even after Jones, "[e]xcessive fee liability has been implemented so poorly that the questions about its abstract value are almost beside the point." 34 In companion empirical work, they find that the size of a fund adviser is a more powerful predictor of whether it has faced suit than the relative size of the fees it charges. "[A]nd perhaps most importantly," they "found no evidence that fees declined in funds after they had been targeted by $\S 36(\mathrm{~b})$ suits. This is disappointing," given that one "goal of $\S 36(\mathrm{~b})$ is . . . to reduce fees going forward." 35

Given how little impact Jones seems to have had on $\S 36(\mathrm{~b})$ litigation, it might be tempting to dismiss the case, and Posner's role in it, as having little import. Why bother writing a heated dissent from a petition that is usually denied as a matter of course? Why anger colleagues and invite censure from the

31 Id at 353 .

32 See Curtis and Morley, 32 Yale J Reg at 3-4 (cited in note 2).

33 Coates, 6 Duke J Const L \& Pub Pol at 59-60 (cited in note 2).

34 Curtis and Morley, 32 Yale J Reg at 4 (cited in note 2).

35 Id at 12 
Supreme Court? The remainder of this Essay explores why, for Posner, there was no other way. And, by examining the three opinions in Jones in context, it suggests that the law is better off because of it.

A. An Aside

I do not write as a dispassionate observer of Judge Posner. I write, instead, as a former clerk, one who can still vividly recall where I was sitting in the Stanford Law library when I opened an email from Judge Posner inviting me to come interview for a clerkship in his chambers. Time froze. And in ways that I could not have fathomed at the time, my response to that email set off a chain of events that transformed the rest of my life. Although I will not recount here the many reasons I am forever indebted to Judge Posner, that gratitude inevitably colors my analysis. I smile whenever I read his words, never quite sure if it is because of the beauty of his prose or the way those words bring him to life before me. I raise this not only to admit my biases, but because specific experiences I had as a clerk shape my understanding of Judge Posner, and sharing a few such moments can shed helpful additional light on who he is and how he judged.

By the time I received that fateful email, Posner was a legend. He was a larger-than-life figure who could loom across continents. This meant that when Posner the Man walked into a room, he had to grapple with the presence of Posner the Legend. He might well have enjoyed this at times, but for someone so eager to learn and engage, legendary status can also take away the fun. The last thing he wanted was to spend time with otherwise intelligent people rendered mute by his glow. So, consciously or not, Judge Posner had devised a set of tools to help ensure that Posner the Legend remained life-sized in conversation, at least when it suited him. I still recall how witty I felt when he seemed to laugh heartily during my interview. Any self-satisfaction disappeared soon after I joined chambers, as I observed him use that same laugh time and again to put others at ease in hopes they might then become more interesting. I told myself that if I were ever to write a biography of Richard A. Posner, which I won't, I would title it "Dick's Laugh," for that laugh, along with his unusual insistence that his clerks address him by his first name-and a nickname at that-embody his unique approach to judging. As a judge, he was a pragmatist and a visionary, as all know, but he 
was a particular breed of pragmatic visionary, one who knew where he stood, or at least had some sense of those contours.

\section{B. Three Opinions, Three Approaches to Judging}

With this background, we can revisit the three opinions in Jones, stylizing each approach just a bit and putting each in context, to consider the role of different actors in the judicial system given the aim of "good" law. The claim is that the occasional instigator is a good thing for the law.

1. The initial instigator.

In Jones $v$ Harris Associates, ${ }^{36}$ Judge Easterbrook plays a role that Posner often plays-instigator. Confronted with a case that could easily be resolved without stirring any feathers, Easterbrook used the case as an opportunity to step back and consider what was at stake and how the law had gotten to its current state. To paraphrase, he said, "I recognize the word 'fiduciary,' and based on my three decades on the bench, I don't think it can bear the load that Gartenberg places on it. I also know something about markets, and something about judges, and those experiences suggest that markets are far better than judges at determining the appropriate price to pay for mutual fund advisory services. Congress does seem to want courts to play a role, but that role is best understood as complementing a market-based regime by ensuring that advisers disclose what they charge and don't engage in tricks. So I will uphold the decision of the district court, but I will also use the case to promulgate a new view of the law."

There are weaknesses to a judge instigating in this fashion. There is a risk of disruption and distraction, particularly if there are too many trying to play this role. The law often exists as it does for a reason. But put in the context of a multilayered legal system, there are also real benefits to judges occasionally playing this role. In purporting to provide answers, Easterbrook was asking questions central to $\S 36(\mathrm{~b})$ yet relatively unaddressed in the decades of litigation invoking it.

The law can stagnate when no one is willing to stick her neck out and ask the tough questions. Sometimes the role of instigators is to draw attention to the ways in which new developments, new insights, or changing mores render the state of the law ill suited 
to the tasks at hand. Other times, the role of an instigator is to question whether there was ever a method to the madness embodied in established doctrine. Law is sometimes the byproduct of thoughtful reflection and application, but it can also spread through inadvertence and inattention. Judges are busy. Dicta in one case can become a holding in the next and all that follow without anyone raising the first-order questions that animated Easterbrook and Posner in Jones. In an imperfect system, instigators can make it more likely that there is a method to the madness. The extensive secondary literature on $\S 36(\mathrm{~b})$ suggests that excessive fee litigation was imposing real costs on large mutual funds without having much of a beneficial impact on fee levels. Given the massive growth of mutual funds and other developments since 1982 when Gartenberg was decided, the appropriate contours of $\S 36(\mathrm{~b})$ liability merited more consideration than they had received. ${ }^{37}$

\section{Posner as instigator.}

Let's now turn to Posner, and what makes him such a valuable instigator. Posner was not the initial instigator in Jones, but he was an instigator. He exercised his vote and voice in a procedural setting when such tools are rarely used. He was not assigned to Jones. He had the option of staying out of the matter completely. But he didn't. Instead, he authored an opinion that had no legal force for little reason other than to explain why the case mattered and why the opinion should not stand. This took time, attention, and the willingness to offend a colleague. We can never know the counterfactual, but we do know that his gambit worked. His opinion helped get the attention of the public and of the Supreme Court, leading to the reversal of Easterbrook's opinion.

Although speculative, it is possible that Posner's gambit had other payoffs as well. Academics are again taking up the question of the appropriate role of law in checking mutual fund fees. ${ }^{38}$

37 See generally, for example, Morley and Curtis, 120 Yale L J 84 (cited in note 2); Coates, 6 Duke J Const L \& Pub Pol 58 (cited in note 2). See also William A. Birdthistle, Investment Indiscipline: A Behavioral Approach to Mutual Fund Jurisprudence, $2010 \mathrm{U}$ Ill L Rev 61, 87; Curtis and Morley, 32 Yale J Reg at 3 (cited in note 2); Brief of Law and Finance Amici Curiae in Support of Respondent, Jones v Harris Associates, No 08-586, *13 (US filed Sept 3, 2009); Brief for Amici Curiae, Professor Deborah A. DeMott and Professor Mark L. Ascher, in Support of Petitioners, Jones v Harris Associates, No 08-586, *23 (US filed June 17, 2009); John C. Coates IV and R. Glenn Hubbard, Competition in the Mutual Fund Industry: Evidence and Implications for Policy, 33 J Corp L 151, 154 (2007).

38 See notes 2, 29. 
Moreover, since 2009, there has been a significant shift from actively managed mutual funds to more cost-effective alternatives like index funds. The crisis surely helped spur this shift, and the trend started before Jones, so other forces are at play. ${ }^{39}$ Nonetheless, the trend is more pronounced in the United States than elsewhere, leaving open the possibility that Jones may have played a contributory role in drawing the public's attention to the mismatch between the fees they were paying and the value they were receiving. ${ }^{40}$

Returning to his influence inside the judicial system, Posner is a self-identified pragmatist. For him, pragmatism is "an approach to decision making that emphasizes consequences over doctrine" 41 and pragmatic judges are "[j]udges who don't insist that a legalistic algorithm will decide every case." 42 Pragmatism as he practiced it thus means both a way of judging and a way of owning those judgments. One cannot be separated from the other.

This understanding of what judges ought to do goes to the core of Posner's sometimes harsh exchanges with Justice Scalia. In Posner's view, the law does not just allow, but requires, judges to exercise judgment. This does not mean ignoring text or precedent. It is about the need for law, statutory or otherwise, to be interpreted, brought to life, and given meaning by judges. It is about a legal system that relies on judges who are human and who see the humanity of those before and around them. It is about being willing to exercise judgment and being frank about those judgments.

Posner doesn't engage in subterfuge, well-meaning or otherwise, when deciding a case. He makes his rationales plain, allowing other judges, other lawmakers, and anyone else who might be interested, to assess for themselves the issues at stake. This comes through in Jones, in Posner's embrace of what the crisis revealed regarding the pervasive problems plaguing finance. ${ }^{43}$ It also comes through in his willingness to look to recent work on the myriad reasons that market forces cannot be trusted as fully

39 See Vladyslav Sushko and Grant Turner, The Implications of Passive Investing for Securities Markets, March Bank Intl Settlements Q Rev 113, 117-19 (2018).

40 See id at 116.

41 Richard A. Posner, The Rise and Fall of Judicial Self-Restraint, 100 Cal L Rev $519,539(2012)$.

42 Id.

43 Jones v Harris Associates, 537 F3d 728, 730-31 (2008) (Posner dissenting from denial of rehearing en banc). 
as he himself once believed. He was capable of having his thinking evolve in light of new evidence, and his assessment of the issues before him shaped by the zeitgeist of the moment, because that is part of what he assumed a good judge does. He looked at the text, but he did not blind himself to realities apparent only by looking away from the text to the litigants before the court and to the world that surrounds them all.

To be sure, there are plenty of risks in allowing Easterbrook, Posner, or others to instigate in this manner. The most pressing may be that in embracing some judicial diversity, similar litigants may face different outcomes, undermining one sense of fairness that is obviously core to the judiciary. Instigating, however, need not affect outcomes. At least some of the time, when Posner took on this role, and the law as it stood was at odds with what he thought it ought to be, he followed precedent while flagging (sometimes successfully) why the law was suboptimal. ${ }^{44}$ Similarly, here, the plaintiffs would have lost regardless of the test used to dismiss their claims.

More importantly, ensuring comparable outcomes in comparable cases is but one measure of fairness. Ensuring that all litigants receive outcomes consistent with the aims and design of the law governing their actions is another. Recognizing the many reasons the law on the books can vary from this notion of "good" creates a space, a need, for instigators even if it does mean some variation in outcomes. The analysis here further suggests that, because no judge is omniscient regarding a law's aims or effects, a pragmatist who openly questions a law's aims and effects, and who does so from a position that is grounded in experience rather than purporting to derive legitimacy from on high, may play a particularly important role in instigating reconsideration of current doctrine.

44 See, for example, Khan v State Oil Co, 93 F3d 1358, 1363 (7th Cir 1996) (adhering to Supreme Court precedent despite criticizing its "increasingly wobbly, moth-eaten foundations"-an approach praised by the Supreme Court when it subsequently overruled its precedent in State Oil Co v Kahn, 522 US 3, 20 (1997)); Planned Parenthood of Wisconsin $v$ Doyle, 162 F3d 463, 479-80 (7th Cir 1998) (holding unconstitutional a Wisconsin law criminalizing partial-birth abortion under the Supreme Court's settled "undue burden" standard, but nevertheless noting aspects of the law that would fail rational basis review-reasoning adopted in part by a Supreme Court majority in Stenberg v Carhart, 530 US 914, $952(2000))$. 
3. Why stick my neck out when there's a nice hole in front of me?

The increasingly normalized sense that judges should not exercise judgment comes through in Justice Alito's chiding of both Easterbrook and Posner. ${ }^{45}$ Neither suggests a reading of $\S 36(\mathrm{~b})$ that ignores the text. They were offering alternative readings of that text. Even Easterbrook, who was closer to the line, grounds much of his analysis on the meaning of a term-fiduciary-which has long been brought to life through judicial lawmaking. ${ }^{46}$ It is also a term, as Justice Alito's opinion otherwise highlights, that has been given different meanings depending on the context, leaving courts no way to avoid the task of making meaning in interpreting it. ${ }^{47}$ To be sure, both looked beyond the text to factors that Justice Alito viewed as inappropriate, but whether judges should ever look up from the page is the question at stake in the analysis here.

True to his critique, Justice Alito's attention does not stray too far from the text. And, rather than forging new ground, Justice Alito hews closely to an unsatisfying and ambiguous status quo. This is different than Cass Sunstein-style minimalism, though it might be taken for such. Minimalism is about scope. The compromises that degrade Justice Alito's opinion arise not from its narrowness but from its vagueness. As Professor Coates nicely summarizes: "In enacting section 36(b), Congress gave the federal courts an unappetizing job: to discern limits based on a vaguely stated standard on compensation in what is clearly both a conflicted but also competitive context. That job necessarily involves exercise of judicial discretion." 48 The Court's opinion was deficient because it "punt[ed] the entire shapeless mess of section 36(b) back to the federal district courts" and "squashed the nascent effort by the Seventh Circuit to begin th[e] process" of "attempt[ing] to put some order on the chaos invited by the statutory standard." 49

Whatever Congress intended $\S 36(\mathrm{~b})$ to achieve, it cannot fulfill that role unless it has sufficient flesh for its limits to be cognizable to courts and, more importantly, to the boards of directors

45 Jones $v$ Harris Associates, 559 US 335, 353 (2010) ("The debate between the Seventh Circuit panel and the dissent from the denial of rehearing regarding today's mutual fund market is a matter for Congress, not the courts.").

46 See Jones, 527 F3d at 632.

47 See Jones, 559 US at 345-47.

48 Coates, 6 Duke J Const L \& Pub Pol at 64 (cited in note 2).

49 Id. 
of mutual funds. For it is in the boardroom that $\S 36(\mathrm{~b})$ will succeed or fail in having some impact on the fees that mutual funds, and investors in those funds, pay for advisory services. This is why Coates is so frustrated. And empirical work, by Coates and others, suggests reason for concern. Recall that Quinn and Morley's findings suggest that $\S 36(\mathrm{~b})$ hasn't been helpful in reducing fees even at those funds that are sued.50 Section 36(b) may never be a panacea for mutual fund investors, and excessive fee litigation is not suited to be the primary tool for ensuring that mutual fund advisers charge reasonable fees, but Congress added the section for a reason. Although Justice Alito rejected Easterbrook's effort to read it out of the scheme, Justice Alito also turned away from the opportunity-recognized as such by amici on both sides of the issue-to provide much-needed guidance regarding how $\S 36(\mathrm{~b})$ ought to function.

In trying to avoid exercising the judgment required to provide meaningful guidance regarding when the fees a fund adviser charges are so high as to violate $\S 36(\mathrm{~b})$, Justice Alito is like a worker saving for retirement who refuses to place his money in anything other than a savings account at his local, FDIC-insured bank. He may be protected from bank failure and the vagaries of the market, but he is ultimately setting himself (but in this case, the law) up to fail. He is allowing inflation to eat away at his spending power and forgoing an opportunity to diversify into assets that, while individually risky, have over time consistently provided the much higher returns most workers need in order to aggregate the wealth needed to enjoy retirement. Sometimes what seems like the safe path is actually a path toward a slow death. Posner and Easterbrook took positions that recognized this.

The Supreme Court sits at a different place in the legal system, and greater modesty may be warranted accordingly. But modesty can mean many things, and the type of modesty that the Court increasingly insists on exercising may in time do more harm than good. Congress sometimes wants judges, and regulators, to exercise judgment. There is no reason a priori that avoiding such commands is any less disrespectful of Congress than decisions to ignore the text altogether.

50 See Curtis and Morley, 32 Yale J Reg at 4 (cited in note 2). 
Justice Alito seems to suggest that Posner crossed a line in looking beyond the text to understand the text. ${ }^{51}$ The opinion echoes a seemingly growing consensus that judges can and should be dispassionate, distant, and objective to the point of removing who they are from the judicial process. There is something appealing about this in the abstract. Wouldn't the law be fairer, after all, if all those applying it did so uniformly, in a manner more akin to a robot than a human?

The Judge Posner I got to know as a clerk never clung to such illusions. He may have appeared cold to those paying heed to the wrong cues, and like most members of the federal judiciary and most educated white males of his generation, he enjoyed privileges of the kind that can blind. But this is when Judge Posner the judge cannot be divorced from Dick Posner the person. Both were constantly observing, and they were remarkably attuned to what they saw. When deciding a suit challenging a health insurer's refusal to cover bariatric surgery for an insured, Judge Posner rendered a short opinion applying established law and deferring to the insurer's determination. ${ }^{52}$ But, if I may, he did so only after he contemplated and opened himself up to what the decision may mean for the insured. He reflected on the gait and possible discomfort of some of the larger individuals that he saw walking along the beach in Michigan where he spent many a weekend. He followed the law but not blindly.

In addition to seeing those before him, Posner saw himself. Although no one would ever accuse Judge Posner of being a man of the people, he was at least aware that he was not. I recall him discussing over lunch the bubble in which he and his colleagues lived. He saw it symbolized in how they moved from home to work. As he explained it, in contrast to most who worked in the Dirksen Building who relied on public transportation, most judges drove. They did so because they had the privilege of parking in a lot directly underneath the building. Upon exiting their vehicles, they were then shuttled up the building in an elevator reserved just for members of the judiciary. They could thus move from the comfort of their homes to chambers without interacting with anyone, except the guards who ensured their safety, or taking so much as a breath of fresh air. He told the story with the

51 See Jones, 559 US at 353.

52 Manny $v$ Central States, SE and SW Areas Pension and Health and Welfare Funds, 388 F3d 241, 246-47 (7th Cir 2004). 
express point of conveying just how insulated a life it is to be a federal judge. He was the butt of the story.

Judge Posner may have said more absurd things than any other member of the federal judiciary during his time on the bench. As closely as he looked at the world, and as much as he saw, there was a lot he didn't understand. He too is human and has biases that do not always serve him. But he never invoked the illusion that any man-made institution, be it Congress or the judiciary, could be anything other than flawed and human to obscure the fact that in each and every case, he was a human being applying man-made law in a way that would affect human beings and the evolution of the law.

It has become trendy for people of power to deny that they have it. Jesse Eisenger made this point with respect to prosecutors, who never charged any top executive despite all of the seeming misdeeds in the years leading up to 2008, but the story doesn't stop there. ${ }^{53}$ CEOs blame shareholders and a skewed interpretation of the law to pretend that they lack agency when making decisions that harm workers or others. ${ }^{54}$ The President blames Congress when carrying out an enforcement policy that separates children from their parents at the border. ${ }^{55}$ The Treasury Secretary and Chair of the Federal Reserve blame a lack of legal authority for the decision to allow Lehman Brothers to fail, despite the flexibility they found in the law to save other institutions. ${ }^{56}$

Justice Alito's decision here is less extreme than these examples. The Jones decision was no great injustice. But that doesn't render it harmless. When courts again and again duck the opportunity and obligation to forge law and provide useful clarity, they may shield themselves from protests, but they also may contribute to a slow erosion of trust in the judiciary. ${ }^{57}$

53 See generally Jesse Eisinger, The Chickenshit Club: Why the Justice Department Fails to Prosecute Executives (Simon \& Schuster 2017).

54 Multiple CEOs of drug companies have recently explained massive increases in the pricing of critical drugs as obligated by duties to their shareholders. Chris Matyszczyk, Move Over, Martin Shkreli. This CEO Says It's His "Moral" Imperative to Raise a Drug's Price by 400 Percent (Inc., Sept 11, 2018), archived at http://perma.cc/5HCX-QH9R.

55 Julie Hirschfeld Davis, Trump Again Falsely Blames Democrats for His Separation Tactic (NY Times, June 16, 2018), archived at http://perma.cc/KS4Z-XV5A.

56 Laurence M. Ball, Ten Years On, the Fed's Failings on Lehman Brothers Are All Too Clear (The Guardian, Sept 3, 2018), available at http://perma.cc/Q43U-SBUT.

57 As Professor Lawrence Lessig has explained, we are at a historical moment when the public's trust in institutions is faltering, in significant part because of a slow erosion, or "corruption," of institutions that are meant to play important public roles. The combination of judicial avoidance with an exacerbated tendency to disguise the rationales for 


\section{CONCLUSION}

Small-c conservatism has an important role to play in the process of judging. Continuity and consistency in the law requires respect for text and adherence to precedent. We should all be grateful that the judiciary is not constituted of carbon copies of Judge Posner. But it is possible that we are locking up too much of the law in a savings account, only to have it diminish in stature and meaning over time. I am fearful that the tendency of so many, in and outside the law, to defer to institutions and commands as somehow outside themselves is contributing to a slow decay that is eating away at the social core of these bodies.

Judges are not and should not be robots. What they do is not and cannot be rote. Judges at their best respect their role as something larger than themselves, deferring to text, precedent, and other constraints accordingly, but also embracing the humanity, quirks, and even warts of all of the constituents whose collective actions contribute to this corpus we call law. There will never be another judge like Judge Posner, but for the sake of the law, I hope that a few more life-sized, larger-than-life figures come to the fore.

that avoidance may be contributing to this institutional corruption. Lawrence Lessig, America, Compromised 1-3 (Chicago 2018). 